Article

\title{
Expanding Access to Higher Education and Its (Limited) Consequences for Social Inclusion: The Brazilian Experience
}

\author{
Elizabeth Balbachevsky ${ }^{1, *}$, Helena Sampaio ${ }^{2}$ and Cibele Yahn de Andrade ${ }^{3}$ \\ ${ }^{1}$ Department of Political Science, University of São Paulo, 05508-060 São Paulo, Brazil; E-Mail: balbasky@usp.br \\ 2 Department of Social Sciences, Faculty of Education, State University of Campinas, 13083-970 Campinas, Brazil; \\ E-Mail: hsampaio@unicamp.br \\ ${ }^{3}$ Centre for Public Policy Studies, State University of Campinas, 13083-970 Campinas, Brazil; \\ E-Mail: cibele@nepp.unicamp.br \\ * Corresponding author
}

Submitted: 1 July 2018 | Accepted: 24 September 2018 | Published: 10 January 2019

\begin{abstract}
This article adopts an historical institutionalism perspective (Pierson, 2011; Pierson \& Skocpol, 2002; Thelen, 2014). Its main goal is to understand the lasting dynamics and path dependency processes that constrain the impact of expanding access to higher education $(\mathrm{HE})$ in changing the pattern of social inequalities in a given country. To do this, the article will explore two different aspects of the impact of education on social inclusion: the dynamics associated with production and distribution of portable skills and competences, and the dynamics associated with social stratification. The study follows the experience of Brazilian HE over the last 15 years. In this period, the country experienced a rapid expansion, coming from a total undergraduate enrolment of 2.7 million in 2000 up to nine million in 2016. Nevertheless, the design of this expansion assumed a very conservative pattern. Following a well-ingrained domestic pattern, most of this expansion was absorbed by the country's huge demand-driven private sector, and into less than half a dozen very traditional types of bachelor programs. Thus, the article argues that by failing to diversify, and by preserving old institutional hierarchies, expanding access to HE in Brazil has rendered less impact than one would expect on the country's social inequalities.
\end{abstract}

\section{Keywords}

access; Brazil; competences; diversification; dualization; education; higher education; skills; social stratification

Issue

This article is part of the issue "Inequalities in Access to Higher Education: Methodological and Theoretical Issues", edited by Gaële Goastellec (University of Lausanne, Switzerland) and Jussi Välimaa (University of Jyväskylä, Finland).

(C) 2019 by the authors; licensee Cogitatio (Lisbon, Portugal). This article is licensed under a Creative Commons Attribution 4.0 International License (CC BY).

\section{Introduction}

Education, and more specifically higher education (HE), is seldom an area of interest to political scientists. While the theme has long raised interest among sociologists and economists, political science has been conspicuously absent in the debates of education in general and $\mathrm{HE}$ in particular. Most recent contributions to the area are focused on issues related to governance of the field and of institutions, and there are few analyses that approach the issue from the perspective of its consequences for the processes of social exclusion/inclusion. In fact, most of the literature tends to accept the notion that expanding access to HE should be taken as equivalent to social inclusion, without further problematization. This article raises some considerations on this equation when exploring the social consequences of the expanded access to $\mathrm{HE}$ experienced by Brazil in the last two decades.

\section{Theoretical Framework}

The theoretical framework employed in this analysis is historical institutionalism. We are mostly interested in the shadows cast by old social dynamics of exclusion on 
new processes of expanded access to HE experienced by Brazil over the last two decades. Three concepts, central in this school of thought, are relevant for our analysis: first, its emphasis on path-dependency dynamics that narrow the number of policy alternatives open in any given conjuncture (Mahoney, 2000; Pierson, 2000, 2011). Second, the concept of institutional layering, i. e., the processes of producing, changing and adapting institutional rules as actors face new problems with an institutional framework developed under different past circumstances. This dynamic ends up producing different layers of institutional logic inside the same organization, which can be mobilized by different actors to face new challenges arising from novelties in the institutional environment or created by the internal struggles for power and dominance (Thelen \& Mahoney, 2010). Third, there are the reinforcing dynamics produced by institutional complementarities coming from changes in different institutional settings (Crouch, 2010; Hall \& Soskice, 2001).

\section{Access to Education and Social Inclusion: Mapping National Regimes of Skill Formation and Social Stratification of HE}

The main effects of education on social inclusion are related to two different, yet interrelated, social dynamics: first, education is intrinsically connected with the processes of creating and upgrading skills and competences that are valued in society as whole, and specifically in the labour-market (Busemeyer \& Trampusch, 2012; EstevezAbe, Iversen, \& Soskice, 2001; Iversen \& Soskice, 2001; Thelen, 2014). Second, education is linked to the processes of social stratification by regulating access to social and cultural forms of capital that are valued by society (Bourdieu 2011/1986). While the first dynamic is a byproduct of all levels of education, the second is strongly linked with patterns of access to the higher levels of the educational pyramid, and, in particular, to university education. Analysing access to education through the first dynamic provides understanding of a country's national regime of skills development. Analysing patterns of access to HE from the perspective of the second dynamic direct the analyst's attention to the processes of differentiation and social stratification present in all systems of $\mathrm{HE}$.

There are two relevant dimensions of the differences in the design of the national regimes of skills development to consider: first, the degree of inclusiveness present in the educational pipeline leading to HE. Here, countries can be differentiated considering the barriers their educational system pose on the route leading to university education specifically, and to HE in general. Another dimension relates to the number and quality of skills and competences that students leave the educational system with at all levels. In this last regard, countries are separated into those offering a unitary system of education, where access to relevant and portable skills are restricted to those reaching higher education, and those where learning paths leading to relevant and portable skills are also available (and widespread in the system) at other levels of education (so-called vocational education). Considering the exhaustively documented correlation between educational success and social origins, it is clear that the presence of a robust vocational system catering to those leaving earlier the educational pipeline means that children from lower income families have access to alternatives for upgrading their skill profile before starting work, instead of entering the labour market with no more resources than a plain, cheap, and undifferentiated work capacity. However, the design of a robust vocational system is often combined with a more exclusive path leading to university education and may represent a relevant barrier for children from lower income families.

Combined, the two dimensions sketched above produce a typology that enable us to better explore how the educational system operates for reinforcing or for attenuating the reproduction of social inequalities. In fact, countries where access to HE is wide, and learning paths leading to relevant and portable skills are open at different levels of the education pipeline are those marked by strong social inclusion dynamics, and where the credential value of a HE diploma has lower impact on social stratification. An example of this profile are Scandinavian countries. Countries with a unitary educational system, but with a high degree of inclusiveness, meaning that a large proportion of the youth reaches (and finishes) HE, are the ones where the channels for social mobility are large, but where education reinforces social-stratification. An example of this is the United States. Countries where a highly exclusive educational path leading to university education works in parallel with a large and inclusive vocational system are those where social hierarchies are strong, but where a skilled working-class is able to command a high level of earnings. An historical example of this situation is Germany at the beginning of the 20th century. Finally, countries where education is exclusive, leading to a high dropout rate, and unitary, offering few alternatives for acquiring workrelevant skills and competences outside $\mathrm{HE}$, are marked by strong social hierarchies and weak social inclusion dynamics, composing what the literature calls the low skills bad-job trap (Snower, 1994). This characterises the experience of many emerging countries, and most specifically the historical experience of Brazil.

From the perspective of the processes of differentiation and social stratification present in all systems of HE two other dimensions are also important: first, the intensity of stratification and the differential prestige associated with different institutions and kinds of degrees granted by tertiary education. Second, how exclusive each educational route inside $\mathrm{HE}$ is, i.e., how much the choice of one route creates costs for ulterior changes in the learning trajectory. In some countries, not only is access to $\mathrm{HE}$ widespread, but it is also done through a more or less homogeneous system, composed by universities 
of similar prestige granting a similar array of certifications and degrees, which creates a relatively flat national $\mathrm{HE}$ landscape where expanding access to HE has strong effects on social inclusion. In other countries, access to HE expanded inside more or less homogeneous systems in terms of types of degrees institutions but marked by strong hierarchies of prestige associated with different institutions and sectors. Here, the effects of access to HE on social inclusion are mitigated by the differential access each institution opens to social and cultural forms of capital. In other countries, access to HE is also wide, but done through two (or more) differentiated institutional profiles of organisations, each providing different portfolios of degrees. Robust binary systems are a historical inheritance of the country's experience with strong vocational training systems. Traditionally, these countries depart from a highly hierarchical HE system, where a small number of highly selective institutions control access to social and cultural forms of capital, providing the basis for the reproduction of the country's elite (BenDavid, 1977). From this point of departure, the literature that explores the contemporary dynamics experienced by these countries (Maassen, Moen, \& Stensaker, 2011; Pinheiro, 2013) points out two different trajectories: one marked by intense processes of academic drift, merging, and collaboration, where the institutional designs of contemporary universities of applied science and of traditional universities converge, which reinforces the channels of student circulation. The other development path tends to preserve differences, even when the country adopts policies targeting to equalize the social prestige attached to the different trajectories of learning.

\section{The Brazilian Historical Experience: Enlarging Access and Preserving Hierarchies}

Brazil is a newcomer to HE compared to other Latin American countries. The first institutions of higher learning were created at the beginning of the 19th century, alongside the country's process of independence. At that time, $\mathrm{HE}$ was an elite endeavour. Its main goal was to train high-level professionals deemed necessary for building the new nation-state. Therefore, the overwhelming influence of the model of Napoleon's Imperial French HE is no surprise. The first HE institutional model adopted in the country drew inspiration from the grandes ècoles. They were independent schools organised for training and certifying professionals in a specific professional track. This model responded also to the aspirations of the local elites. A professional degree was the primary signal of prestige and differentiation in local societies. Holders of these degrees enjoyed esteem, had access to secure posts in the high bureaucracy and the clergy, and could aim towards the most senior positions in the country's political, economic and military life. The first universities in the country were only created in the 1930s. Even then, the newly created universities preserved the core traits of the so-called Napoleonic model, a loosely-coupled in- stitution, composed of semi-autonomous professional schools, each of them dominated by the ethos of a particular profession, to which a new unifying component was added: a Faculty of Philosophy, Science and Humanities, which was expected to carry out some research and train specialized teachers for secondary education.

The first critical juncture that conditioned the contemporary development of HE in Brazil was established at the end of the 1960s. A structural dependence on the private sector for answering the demands of access was created. At that time, two different dynamics were responsible for this critical juncture. There was a first wave of demand for expanding access to HE caused by increasing access to secondary schools since the 1950s. By the mid-1960s, the number of youths holding secondarylevel qualifications and passing the entrance examinations organized by each university but left without access to the HE because of the limited number of entrypositions opened by these universities started to increase. This situation gave rise to a social movementthe "movimento dos excedentes" - which were then mobilized by the oppositionist political agenda of resistance to the military government that replaced the democratic regime in 1964.

The increased demand for access was concurrent with another dynamic arising from a push for reform in public universities. In 1968, the military government adopted a comprehensive reform which tried to depoliticise the internal environment of public universities by responding to some demands posed by the sectors interested in improving the institutional framework supporting research. The reform of 1968 implanted full time contracts in public universities, replaced the old chair model with the departmental model, stimulated the dissolution of the old faculties of philosophy, science and humanities into a number of specialized institutes and faculties, and adopted a credit system (instead of the old sequential model) for bachelor programs (Klein, 1992). Even if the Reform faced resistance among the faculty of the most traditional professional schools and mistrust among other academics and students, it was successfully implemented in the entire public sector. However, the success of the reform also increased the costs of public universities. Estimates made by specialists show that, between 1972 and 1986, the budget of federal universities grew 5.4-fold, most of it consumed by opening full-time contracts to all academics in these universities, without a significant expansion of enrolment at undergraduate level (Schwartzman, 1993; Velloso, 1987). With the superimposition of these dynamics, expanding the private sector became the best policy alternative in the eyes of the government. It was a cheaper response to the "movimento dos excedentes", with the added gain of helping to weaken the student movement concentrated in large public universities, then one of the most prominent sources of opposition to the military government.

Private HE was legally permitted in the country since 1945. However, prior to the 1960 s, the choice for private 
learning was mostly dictated by the students' family religious or other values. Most of the private sector was made up of Catholic and other denominational universities, following the institutional design of public universities. The other common organisational format was the school of commerce, focusing on providing training paths for white-collar jobs (Sampaio, 2000). The second edition of the country's Education Law (the Lei de Diretrizes e Bases da Educação, 5.540/1968), from 1968, revived the independent faculty or school as an alternative institutional design to the university model for teaching and granting degrees at the bachelor's level. While, ideally, this should be a provisional arrangement as the organisations were expected to grow and become full-fledged universities, the new institutional design became a permanent part of Brazilian $\mathrm{HE}$. The private sector grew as a cheap route for expanding access to HE (Martins, 2009), and the system experienced a wave of organisational differentiation without diversification in degrees and career paths. The private sector grew as a parallel system, mostly organised in small units offering evening courses, catering to students who could not perform well in the entrance examinations to the public sector, which lost its qualifying nature to become simple classificatory exams, designed to select the best ranked students to fill the entering positions opened by the university for each bachelor's program (Balbachevsky, Kerbauy, \& dos Santos, 2000).

Protected from the worst sequels of massification, Brazilian universities followed a different path to the one experienced by public universities in many Latin American countries, where it was the public universities that answered to the demands for access to HE in the 1970s. There, the public universities expanded to became what is known regionally as the mega-universities. The main traits of a mega-university are its very large body of undergraduate enrolments, with hundreds of thousands of students, taught by a large and highly segmented faculty body, which includes a high proportion of academics with per-hour paid contracts, and the presence of specialised bodies dedicated to research where full-time academics develop research and postgraduate education. In Brazil, however, from 1968 public universities evolved to adopt the organizational features of research universities, employing mostly academics in full-time contracts with low teaching loads. A post-graduate, academically oriented, training path was legally recognized and structured in 1964 and grew at a fast pace since. A federal agency-CAPES-strengthened its position inside the Ministry of Education and won a central role in the schemes for supporting graduate education through dedicated funds directed to graduate programs inside the universities and a large program of scholarships for graduate students. With this support, and counting on good institutional conditions, Brazilian graduate education expanded to become one of the largest systems in the world. While external quality assurance mechanisms for undergraduate programs were only developed in the 1990s; in the case of postgraduate education, the scientific community allied itself with the high bureaucracy from CAPES to create a comprehensive mandatory evaluation based on peer-review, in place since 1976.

From the late 1960 s onwards, access to basic education-including primary and low-secondary education-also experienced rapid expansion, adopting a more inclusive design for the first time. Primary and lower secondary education were conflated into a single mandatory level of education attending children from seven to 14 years old, and the traditional entrance examinations for the lower-secondary education were abolished. However, here the country experienced a similar dynamic as the one found in $\mathrm{HE}$, with the growth of a large number of private institutions. Only, at this level, the differentiation took an inverse trajectory: while the public sector massified and quality declined, the private sector attracted children from the upper-middle classes. The selective exit of the students from families more likely to voice dissatisfaction with the deterioration of the quality of education worsened the situation of public basic education and left it without resources for fighting the trajectory of deterioration, following a general dynamic first described by Albert Hirschman (1970). This change has a reinforcing mechanism: as quality deteriorates in the public sector, it become more and more confined to the role of a second-class alternative of education, which is shunned by the children from middle classes, which, in turn, aggravates the processes of deterioration. From middle 1970s, public basic education had already been converted into an education for the poor, marked by strong class stigma.

Meanwhile, the limited demand for qualified workers coming from the most dynamic sectors of the economy was met by a very peculiar and successful institutional arrangement created in the 1940s, known as System S. ${ }^{1}$ The entire arrangement is financed by a levy applied to the profits of all firms. It is sectorial, regionally organized and directedly managed by the corporate sector, which assures that the skills developed precisely meet the particular needs of firms (AssumpçãoRodrigues, 2013). Besides this successful but limited initiative, the Federal government and the states governments also organized networks of vocationally oriented secondary schools in the 1960s. Nevertheless, this sector was (and still is) small and selective, with access regulated through entrance examinations. The selectiveness of public vocational education prevented it from becoming a real alternative for access to relevant and portable skills for the children dropping out of school before reach-

\footnotetext{
${ }^{1}$ System S refers to a set of non-state organizations established since the 1940s, dealing with vocational training. The most important are: National Industrial Apprenticeship Service (SENAI), created in 1942, Commerce Social Service (SESC), National Commercial Apprenticeship Service (SENAC), and Industry Social Service (SESI), created in 1946, Brazilian Small and Medium-Size Businesses Support Service (SEBRAE), created in 1972, and a number of other institutions.
} 
ing HE. As general basic education in the public sector lost quality, by contrast the academically selective public vocational system converted itself into a successful route to access to the valued public university education for the more able children from lower-middle income families. Thus, vocational learning become a complement, added to a more generalist curriculum, which evolved by focusing on preparing the students to face the demanding examinations which controls access to $\mathrm{HE}^{2}$

The dynamics described above trace the development of the main elements of the Brazilian regime of skills development at the end of 1990s. It was organized in the shape of a very long pipeline, with almost no de facto lateral exits, where the access to relevant and portable skills are mostly available at the HE level. Preparing students for the path leading to $\mathrm{HE}$ is the dominant objective of education at all lower levels, even inside the small public vocational sector. This general design means that by leaving the school before finishing a first level university training, youths face the labour market without any particular set of skills or competences. For the losers in this competitive game, the only learning option available is the narrow on-job training provided by firms.

\section{Stratification and Access in Brazilian HE}

The combination of all these dynamics produced a heavily stratified system of HE with a high degree of institutional heterogeneity. At the end of the Military Regime, in 1989, at the top of the system, there was (and still is) a number of comprehensive, tuition free, public universities. Among them, a smaller number of active research universities, with a relevant proportion of enrolments at postgraduate-master's and doctoral training programs ${ }^{3}$ - command most of the academic prestige inside the country. Besides this select group of universities, there are some private denominational universities of great prestige. Below them, there was an incredible array of private institutions-some legally recognized as universities, some organized in federations of faculties, and most of them with the format of independent schools or faculties, all catering to students to children from lowincome families in search of social mobility.

Despite this institutional diversity, the system was highly homogeneous in terms of the credentials it granted: except for some transient experiences in teacher education, for the entire last century all institutions in the Brazilian HE granted the same first degree, the professional bachelor's degree after a period of training varying from four to six years. While the comprehensive public universities showed a degree of heterogeneity considering the number of knowledge areas these degrees covered, the system as a whole converged to granting degrees in a small number of areas: pedagogy (which is a degree giving access to teaching positions in basic education), law, business administration, and health sciences (some medicine, but mostly psychology, nursery and odontology). In 1998, 62\% of all degrees granted in the country were concentrated in only ten areas. Among these areas, two career paths-Law and Business Administration-were responsible for $26 \%$ of all degrees granted in the country (INEP, 2000).

From the point of view of social stratification, it would not be a misrepresentation to consider this education system as a sound-box, reproducing and magnifying the patterns of social exclusion present in society. In 1994, less than $8 \%$ of all youths aged between 18 and 24 years old were enrolled in HE. Among them, slightly more than $2 \%$ had access to the prestigious tuition free public universities. Furthermore, by combining a low quality public primary education with an academic oriented secondary school, the school system actually functioned as a filtering devise, selecting the most appropriate candidates for university life, while neglecting all other profiles. Particularly, secondary education operated as a stringent bottleneck, filtering a relevant proportion of youths out of school. At the beginning of 1990 s, over $43 \%$ of youths from 15 to 17 years did not attend school.

\section{Changing Access to Education: The New Dynamics Opened by the Democratic Experience}

Democracy returned to Brazil at the end of the 1980s. The new Constitution was promulgated in 1988, and in 1990 the first elected President took office. Between 1990 and 1994, the country faced a turbulent period with extremely high inflation rates and low rates of economic growth. In 1994 a successful economic stabilization plan brought Fernando Henrique Cardoso into office, sustained by a large alliance between the centre and centre-right, followed by the administration of Luis Ignácio Lula da Silva, a president elected from the leftist Workers' Party (known as PT) in a broad coalition which unified the left and right, bypassing the centre and the centre-right parties. Mr. Cardoso governed Brazil for eight years (from 1994 up to 2001), and Mr. da Silva for the following eight years, from 2003 to 2010, and selected his successor, President Dilma Rousseff, also from the Workers' Party.

The main achievements of Cardoso's administration were in primary education, mostly focused in expanding enrolment and lowering the level of dropout. Cardoso's administration introduced a major change in the financ-

\footnotetext{
2 Before the last reform of 2017 that radically reduced the number of mandatory disciplines, all Brazilian students-including those enrolled in the vocational sector-were supposed to learn mathematics, physics, chemistry, biology, sociology, world history, Latin-American history, and Brazilian history, world geography, with special emphasis on the Latin America region and Brazilian geography, philosophy, Portuguese grammar and writing skills, Brazilian literature, English and Spanish languages. Not only were there a large number of disciplines, but the roll of subjects inside each discipline is extensive: in physics, for example, the student is supposed to learn mechanics, the laws of movement and of conservation of energy, elements of astronomy, physics of fluids, thermodynamics, waves, optics, electricity and electrical magnetism.

${ }^{3}$ For an analysis of the growth of research universities in Brazil see Balbachevsky (2013).
} 
ing scheme for primary education, by diverting a relevant amount of federal resources toward the Fund for Support and Development of Primary Education and Valorisation of Teacher Profession (FUNDEF). These resources were made available to municipalities to support improvements in primary education, as well as in teachers' salaries, which until then had been the sole responsibility of municipalities. Access to the resources of FUNDEF was conditioned by the performance of the municipal authorities, taking into account the level of coverage of primary education and a number of other indicators. At the same time, the government prohibited the practice of holding back under-performing students in the first years of school. This was a relevant bottleneck preventing a large number of children, especially those coming from poor, less educated families, to complete primary education. The results of the two combined initiatives were impressive: in few years the country reached universal access to primary education, with the net enrolment at primary education rising from $87 \%$ in 1994 to $94 \%$ in 2000 (IBGE, n.d.-b). With a growing number of children finishing primary studies, the country also experienced an explosive growth in enrolment at the secondary level. During his government, the percentage of youth between 15 to 17 years old attending school rose from $57 \%$ to $75 \%$ (IBGE, n.d.-b).

It was also during Cardoso's first term that a new Education Act was approved by the Congress and enacted by the Presidency, in 1996. The law introduced a number of relevant changes in the normative environment of HE. First, the Law imposed new general parameters under which a HE institutions could be authorised (and, for the first time, re-authorised every five years) to hold the title of a university. At the same time, it differentiated and recognized other institutional profiles, including teaching-oriented institutions and private for-profit institutions. Another relevant innovation was the diversification of the portfolio of first level degrees any institution could grant: besides the traditional bachelor's and teaching license (the latter now established as a third level degree), it also introduced the technological degree, a vocational degree granted after three years of study, and opened the possibility of mid-term certification in a bachelor's program track, then called sequential programs-“cursos sequenciais". Under this model, the bachelor's program could be organized into two halves, opening the possibility of a certified lateral exit-which also allowed for a later return to studieswhen the student finished the first half of the study program. Overall, innovations were mostly adopted in the private sector, where old programs experienced intensive redesign, new programs were launched, some with a modular approach, and technological programs were started. The public universities resisted change, proclaiming loudly that the old bachelor's program was the only degree acceptable for a university. In this sector, there were only few experiments with curriculum reform, and even at postgraduate level most public universities re- frained from diversifying their portfolio by incorporating the alternative of professional master's degree now recognised by the government.

Finally, Cardoso's government was also marked by two other initiatives: a bold move toward controlling the quality of HE through a general evaluation applied to all graduating students coming from bachelor's programs, and the adoption of a number of evaluations for accessing the system performance at different levels: the "prova Brasil" which evaluated the performance of a sample of students in their 6th and 7th years of study, the ENEM ("exame nacional de ensino médio") designed to evaluate the performance of students leaving highschool, as well as volunteering the country to take part in the PISA exercises organized by OECD.

\section{Access to HE and Social Inclusion: The Legacy of the Left}

Mr. da Silva's election, in 2002, relied on the backing of a large majority of the country's lower middle-class and the organized sectors of society represented in unions and social movements. Regarding HE, the first moves of the new government in HE policy answered to two different constituencies, both critical for the new government. In one part, the policy answered to the more ideologically committed sectors by changing the normative environment and imposing stronger controls over the private sector, tightening the rules of evaluation and accreditation, and imposing a ban on opening new bachelor programs with the design of the sequential programs, considered a neoliberal aberration by these sectors. On the other hand, responding to the Party's large constituency of lower-middle income families, the government adopted an aggressive policy toward enlarging access to $\mathrm{HE}$. As had happened in the past, the first moves targeted the private sector. In 2004 the government launched a program called "University for All", which exchanged fiscal benefits for tuition exemption to lower income students in the private sector.

In 2007 the government also started a major program supporting the expansion and reform of the federal universities, the REUNI program (Programa de Reestruturação e Expansão das Universidades Federais). The program set incentives in the form of price signals, conditioning the university's access to new funds for improvements in some critical indicators: the expansion of the number of undergraduate enrolments, targeting particularly enrolments in evening programs; the increase of the ratio of undergraduate students per academic, and the expansion of the proportion of students coming from public schools (taken as an indicator of low-income social background) and minorities. Mr. da Silva also encouraged the adoption of quotas and other affirmative action initiatives, targeting children from minorities and from low-income families. In 2012 these initiatives were consolidated in a new law, reserving half of the entrance positions in the federal universities for candidates coming 
from the public basic education and minorities. Finally, in the area of vocational education, in 2008 the government upgraded and enlarged the federal network of federal colleges for technological education to $\mathrm{HE}$, allowing them to offer programs leading to technical degrees. This shift diversified the federal system that was previously composed primarily by comprehensive universities.

All these initiatives expanded access to $\mathrm{HE}$, and between 2010 and 2012 enrolments in the public sector grew faster than enrolments in the private sector. Even so, this growth was not enough to produce a massive increase in access to HE. the country's gross enrolment ratio in tertiary education remained low. This index reached just $34 \%$ in 2009, which was lower than the ratio of many other Latin American countries (UNESCO, n.d.). Thus, in 2010 , in order to quickly expand the enrolments in $\mathrm{HE}$, the Federal Government opted to reform and expand a subsidised loan program (FIES) to support students enrolled in the private sector. FIES helped to solve a central bottleneck for the growth and diversification of the private sector which was the high level of insolvency in tuition fees, creating the conditions for significant growth of the private sector between 2010 and 2016.

\section{The Conservative Response to Expanding Access to $\mathrm{HE}$}

The first 25 years of democracy in Brazil significantly changed the educational landscape. As seen in Figure 1, among young people from 18 to 24 years old, between 1995 to 2014, the percentage of those who do not finish primary education-which in Brazil constitutes the first nine years of study-dropped from $58 \%$ to $16 \%$. The percentage of those finishing upper-secondary education rose from $12 \%$ to $33 \%$, and enrolments in HE rose from 1.7 million to almost nine million in the same period (IBGE, n.d.-a).

Access to $\mathrm{HE}$ also became more inclusive, though still highly unequal: the percentage of youths from the two lower-income quintiles reaching $\mathrm{HE}$ came from $2 \%$ in 1995 to $12 \%$ in 2014 . Among the youths from the upperquintile, the percentage enrolled in $\mathrm{HE}$ rose from $21 \%$ to $61 \%$ (IBGE, n.d.-a). Here, the most important move against the hierarchical nature of HE in Brazilian society comes from the introduction of an aggressive affirmative action program in Federal universities. As early as 2007 the REUNI program supported the adoption of quota programs in federal universities. In 2012 Brazilian Congress approved a law imposing a reserve of $50 \%$ of all entrance positions in Federal Universities for students coming from public primary and secondary schools, and, among these, reserving some positions for children from black and indigenous families. This move was followed by the state-run universities. These initiatives produced a relevant change in the profile of the students served by prestigious public universities, as it has the potential to change the pattern of access to the social prestige linked to holding a degree from these universities, which is one of the most promising moves in the recent past.

However, the measures guaranteeing access to entry positions public HE for the children from lower-income families and minorities were not followed by a massive program supporting the progression through the institution of this new profile of students. There are some initiatives at institutional level, and a number of smallscale federal programs trying to tackle this problem, but still a lack of a more comprehensive initiative. It is to be noted that, from 2006 to 2016, the ratio between the number of degrees granted and that of the number of admitted students four years earlier dropped from $58 \%$ to $43 \%$ inside federal universities (data from Censo do Ensino Superior, n.d.; tabulation done by the authors). While this decline in the efficiency of federal universities cannot entirely be attributed to challenges faced by the new profile of students when undertaking the most demanding programs, it is clear that, to some degree, the new challenge faced by the federal universities is to provide enough remedial academic support to the new pro-

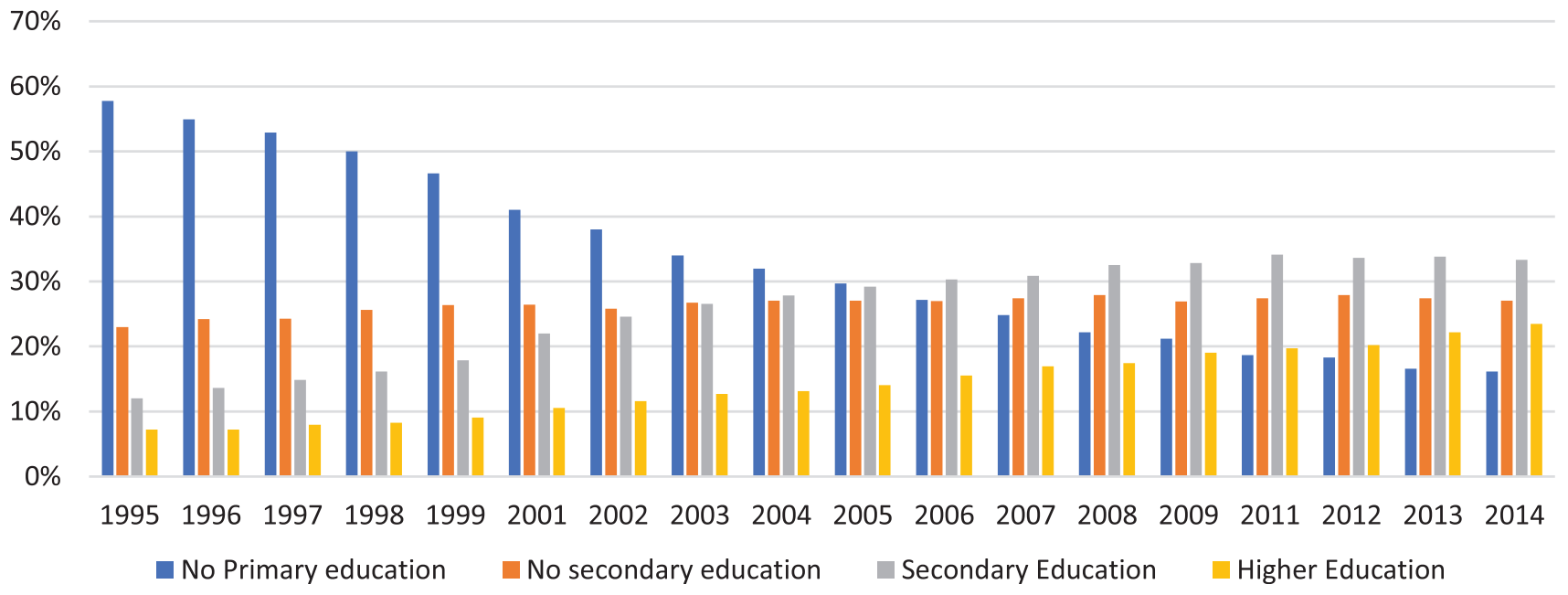

Figure 1. Brazil: Evolution of access to education from 1995 up to 2014, population with 18 up to 24 years old. Source: IBGE, n.d.-a). Tabulation done by the authors. 
file of students, especially to those enrolled in the more demanding programs.

On the other hand, in spite of all changes, Brazilian $\mathrm{HE}$ has remained highly traditional in its design. In 2014, over $61 \%$ of all undergraduate enrolments were still concentrated in only four areas: Business, Social Sciences, Law and Education. Together, these few areas plus engineering and health sciences accounted for $82 \%$ of all enrolments in 2015 , leaving just $18 \%$ of the students for all other areas. A very small number of programs inside each of these areas concentrate a great majority of the enrolments. Thus, Law and Business Administration answer for more than $20 \%$ of all enrolments in the country, and civil engineering makes up for $70 \%$ of all enrolments inside engineering (Censo do Ensino Superior, n.d.).

Brazilian $\mathrm{HE}$ is not only conservative in the profile of competencies and skills it develops. It also resists diversification. In 2014 , only $20.1 \%$ of all first-level degrees granted in the country came from programs exploring new alternatives to learning outside the traditional fouryears bachelor programs. In that year, just $20 \%$ of enrolments at the master's level were in professional master's programs. Despite the diversification experienced by the federal system in 2008 , it is the private sector that is still responsible for more than $91 \%$ of all technological degrees awarded in the country (Censo do Ensino Superior, n.d.).

In fact, in 1996, when the normative environment changed with the new Education Law, the internal stakeholders in public universities banded together against changing their portfolio of programs and training paths. For some of them, the main issue was the fear of losing social prestige, and a clear discomfort with the idea of equalizing the traditional learning path leading to a bachelor's degree with the more mundane training path of technical learning. For others, the conservative response came from an ideological misunderstanding that equates vocational education with class subjugation (Barbosa, 2009). Thus, the alternative design of programs was mostly explored by the private sector, which innovated by introducing programs focusing on new niches created in the labour market, such as fashion design, game design, gastronomy, among others. Another major innovation introduced in Brazilian HE in the last decade is the use of online distance education. Again, distance education is in practice a private endeavour: over $90 \%$ of the 1.4 million enrolments in distance education are in the private sector. The absence of the prestigious public universities in these initiatives helps to limit their impact on social mobility. These innovative paths remain marked as second-class alternatives, and for that reason, their impact on access to learning have had limited consequences for opening access to social and cultural capital. In fact, another relevant change in the Brazilian HE landscape is the presence of strong processes of differentiation and stratification in the private sector, with the growth of a segment of prestigious elite institutions catering to children from affluent families, interested in the selective social environment offered by such institutions.

\section{Conclusion: Expanding Access without Changing the Dynamics of Exclusion}

The changes experienced by Brazil in recent decades has had a relevant impact on the pattern of access to education in general, and on HE in particular. Thanks to the policies adopted in the last three decades, access to $\mathrm{HE}$ has expanded. Because of this expansion, and also because of the bold affirmative action programs adopted at the beginning of the new century, the profile of students attending post-secondary education is also much more diverse today than it was at the beginning of the century; there are more children from poor families, and more female, black and indigenous students. However, most of this inclusion has happened in programs of lower social prestige, if not of lower quality, which lessens its impact in terms of social inclusion (Costa-Ribeiro \& Schlegel, 2015).

Considering the main design of the country's skills development regime, one could say that opening access to HE did expand the outcomes of the country's regime of skills and competences, but its basic shape remained untouched. It is still organized in the shape of a very long pipeline, with almost no de facto lateral exits. Access to relevant and portable skills are mostly available at the HE level, and the main goal of all the first levels of education -mostly of secondary education-is still to prepare the student for the exams that regulate access to $\mathrm{HE}$. The meaningless encyclopaedic mode of learning promoted by this narrow goal accounts for the large volume of dropouts at the secondary education. Thus, the general design of the country's regime of skills development still creates the conditions for a low-skill, bad-job trap for a large number of Brazilian youths.

Inside $\mathrm{HE}$, the design is still highly hierarchical, with a small number of students reaching the prestigious tuition-free public sector-24.7\% of all enrolments, according to the last census of Brazilian HE in 2016. The vast majority attend programs in the demand-driven private sector on programs of lower quality, leading to less valued academic degrees and de facto limiting their academic options after graduation. ${ }^{4}$ The path dependence dynamics established in the 1960s still constrain the policy options open to governments. Expanding access and attending to the demands of education coming from the new generations and from the older cohorts that did not have access to education is done mostly through large for-profit educational conglomerates. The presence of this large for-profit subsector in Brazilian HE reinforces

\footnotetext{
${ }^{4}$ There are no figures available on the previous academic track of the candidates accepted to the postgraduate level. Nevertheless, the data gathered at by the last survey of the academic profession in Brazil, and anecdotical information concur to indicate that attending a bachelor's program in the demand-driven private sector diminishes the probability of access to master's and doctorate programs (Balbachevsky, 2016).
} 
the move towards a strong State presence, imposing regulation and strict supervision over the entire system. In order to control the quality of education, the Ministry of Education developed a huge and detailed system of evaluation following uniform parameters applied to all institutions. In spite of the good intentions, the large apparatus for overseeing the programs had an adverse impact over the private sector, supporting the dynamics of its consolidation into huge for-profit institutions. As argued by de Castro (2015, p. 282): "Instead of controlling market behaviour and making it work better, the quality assurance policies provoked the capture of private HE by investment funds and global groups", which has deepened the hierarchies that organize the country's $\mathrm{HE}$ landscapes.

On the other hand, the public sector also faces challenges when it comes to innovation and social inclusion. Despite efforts and policy initiatives, public universities have a governance model designed to prioritize the demands and views sustained by the internal stakeholders, which are responsible for electing the rectors and the central actors in the university's senate. Most Brazilian universities do not have a board of trustees in their institutional design. When facing demands coming from the government and price signals posed by programs and new policies, most public universities answer strategically, limiting the impact of the changes over their internal environment and protecting the status quo. Most of the push for innovation remain isolated in small internal environments, limiting impact over the university as a whole. This situation makes public universities costly and poorly adapted to responding to the demands for broad social inclusion. The highly prestigious public universities were successful in avoiding adopting a more flexible portfolio of learning alternatives and a new governance framework. This move, while it did preserve the public sector from some side-effects of massification, ended up reinforcing the traditional hierarchy of prestige and social esteem attached to different kinds of degrees. This dynamic also helped to consecrate the conservative approach that holds the bachelor's degree as the holy grail to which the entire system is geared, while undermining the social value of other learning paths.

The deeply-ingrained institutional model of the university-as a research institution with most academics on full-time contracts with low teaching loads-prevalent in the public sector, contaminated the design and development of the new institutional additions of technical colleges, making them too expensive to function as an alternative for answering the demands for access to $\mathrm{HE}$. Finally, the selectiveness of the vocational programs offered in the public sector in secondary education preserve them as an alternative path for access to a public university (Bandera, 2014), and limits their impact over the shape of the country's regime of skills development.

All these traits put education and HE at the service of dynamics preserving dualization in the labour market, which helps to reproduce the inequalities in Brazilian so- ciety. Therefore, focusing the entire policy debate on the issue of expanding enrolment in HE effectively occludes the real focus of social inclusion, which is to achieve a new design in the regime of skills formation marked by different and flexible learning paths. This change would not only help to prepare new generations to face deep changes in the labour market created by the accelerated pace of the technological change, but also improve the opportunities open to the children from poor families. In fact, today, as in the past, the conservative design of the country's regime of skills development denies access to relevant skills to these children, which would allow them to fight against the heritage of poverty and social exclusion. At the other end, the highly hierarchical design of Brazilian HE still prevents, even among those reaching $\mathrm{HE}$, full access to the social and cultural capital that would allow a deep change in the profile of the country's social stratification.

\section{Acknowledgements}

The authors would like to acknowledge the financial support given by FAPESP, Fundação de Amparo à Pesquisa do Estado de São Paulo, and by the Brazilian Council for Research Support (CNPq), project PRONEX 11/50771-8.

\section{Conflict of Interests}

The authors declare no conflict of interests.

\section{References}

Assumpção-Rodrigues, M. M. (2013). Skill formation, governance and democracy in Brazil: The state of art of a public policy. International Journal of Education and Research, 1(2), 1-41.

Balbachevsky, E. (2016). Brazilian higher education: Converging trajectory patterns in a diverse institutional environment. In J.F. Galaz-Fontes, A. Arimoto, U. Teichler, \& J. Brennan (Eds.), Biographies and careers throughout academic life (pp. 31-46). Dordrecht: Springer.

Balbachevsky, E. (2013). Academic research and advanced training: Building up research universities in Brazil. In J. Balan (Ed.), Latin America's new knowledge economy: Higher education, government and international collaboration (pp. 113-133). New York, NY: AIFS Foundation and Institute of International Education.

Balbachevsky, E., Kerbauy, M. T. M., \& dos Santos, V. M. (2000). Brazil. In B. Vlaardingerbroek \& N. Taylor (Ed.), Getting into Varsity: Congruence, convergence and comparability (pp. 255-272). Armhest, NY: Cambria Press.

Bandera, N. D. (2014). Esforçados e talentosos: A produção do sucesso escolar na Escola Técnica Federal de São Paulo [Dedicated and talented: The school success production at the Technical School of São 
Paulo]. Educação em Revista, Belo Horizonte, 30(3), 195-218.

Barbosa, M. L. de O. (2009). Educação tecnológica no Brasil: As desventuras da formação técnica no país do bacharelismo [Vocational education in Brazil: The misfortunes of technical treining in the country of the Bachelors]. Paper presented at the Seminar "Recursos Humanos em Áreas Estratégicas definidas no Plano Nacional de Ciência, Tecnologia e Inovação 2007-2010", Centre for Strategic Studies (CGEE), Brasília.

Ben-David, J. (1977). Centers of learning: Britain, France, Germany and the United States. London and New York: Routledge.

Bourdieu, P. (2011). The forms of capital. In I. Szeman \& T. Kaposy (Eds.), Cultural theory: An anthology (pp. 81-93). (Original work published 1986)

Busemeyer, M. R., \& Trampusch, C. (2012). The political economy of collective skill formation. Oxford: Oxford University Press.

Castro, M. H. M. (2015). Higher education policies in Brazil: A case of failure in market regulation. In S. Schwartzman, R. Pinheiro, \& P. Pillay (Eds.), Higher education in the BRICS countries (pp. 271-289). Dordrecht: Springer.

Censo do Ensino Superior. (n.d). Censo do Ensino Superior [Brazilian census of higher education]. INEP. Retrieved from portal.inep.gov.br/censo-da-educacaosuperior

Costa-Ribeiro, C., \& Schlegel, R. (2015). Estratificação horizontal da educação superior no Brasil (1960 a 2010) [Horizontal stratification of higher education in Brazil (1960 to 2010)]. In M. Arretche (Ed.), Trajetórias das desigualdades: Como o Brasil mudou nos últimos cinquenta anos [Trajectory of inequalities: How Brazil has changed in the last 50 years] (pp. 133-162). São Paulo: Editora UNESP.

Crouch, C. (2010). Complementarity. In G. Morgan, R. Whitley, C. Crouch, \& J. L. Campbell (Eds.), The Oxford handbook of comparative institutional analysis (pp. 117-138). Oxford: Oxford University Press.

Estevez-Abe, M., Iversen, T., \& Soskice, D. (2001). Social protection and the formation of skills: A reinterpretation of the welfare state. In P.A. Hall \& D. W. Soskice (Eds.), Varieties of capitalism: The institutional foundations of comparative advantage (pp. 145-183). Oxford: Oxford University Press.

Hall, P. A., \& Soskice, D. W. (Eds.). (2001). Varieties of capitalism: The institutional foundations of comparative advantage. Oxford: Oxford University Press.

Hirschman, A. O. (1970). Exit, voice, and loyalty: Responses to decline in firms, organizations, and states. Cambridge, MA: Harvard University Press.

IBGE. (n.d.-a) Microdados reponderados da PNAD 20012015 [Brazilian National Household surveys' microdata, 1995-2015]. IBGE.Gov. Retrieved from ww2. ibge.gov.br/home/estatistica/populacao/trabalhoe rendimento/pnad2015/microdados.shtm

IBGE. (n.d.-b). IBGE séries históricas: Taxa líquida de esco- larização por níveis de ensino [IBGE's historical series: Net enrolment rates by educational level]. IBGE.Gov. Retrieved from www.seriesestatisticas.ibge.gov.br/ series.aspx? vcodigo $=$ SEE 17

INEP. (2000). Evolução do ensino superior, graduação, 1980-1998. Brasilia: Instituto Nacional de Estudos Educacionais (INEP). Retrieved from www.download. inep.gov.br/download/censo/1998/superior/evolucao _1980-1998.pdf

Iversen, T., \& Soskice, D. (2001). An asset theory of social policy preferences. American Political Science Review, 95(4), 875-893.

Klein, L. (1992). Política e políticas de ensino superior no Brasil: 1970-1990 (Work Report NUPES 2/92). São Paulo: Universidade de São Paulo.

Maassen, P., Moen, E., \& Stensaker, B. (2011). Reforming higher education in the Netherlands and Norway: The role of the state and national modes of governance. Policy Studies, 32(5), 479-495.

Mahoney, J. (2000). Path dependence in historical sociology. Theory and Society, 29(4), 507-548.

Martins, C. (2009). A reforma universitária de 1968 e a abertura para o ensino superior privado no Brasil. Educação Social, 30(106), 15-35.

Pierson, P. (2000). Increasing returns, path dependence, and the study of politics. American Political Science Review, 94(2), 251-267.

Pierson, P. (2011). Politics in time: History, institutions, and social analysis. Princeton, NJ: Princeton University Press.

Pierson, P., \& Skocpol, T. (2002). Historical institutionalism in contemporary political science. Political Science: The State of the Discipline, 3, 693-721.

Pinheiro, R. (2013). Bridging the local with the global: Building a new university on the fringes of Europe. Tertiary Education and Management, 19(2), 144-160.

Sampaio, H. (2000). Ensino superior no Brasil: O setor privado [Higher Education in Brazil: The private sector]. São Paulo: Hucitec/Fapesp.

Schwartzman, J. (1993). Universidades federais no Brasil: Uma avaliação de suas trajetórias-Décadas de 70 e 80 [Federal Universities in Brazil: An evaluation of their trajectories-the 1970s and 1980s] (Work Report NUPES 4/93). São Paulo: Universidade de São Paulo.

Snower, D. J. (1994). The low-skill, bad-job trap (CEPR Discussion Paper Series no. 999). Centre for Economic Policy Research (CEPR), London.

Thelen, K. (2014). Varieties of liberalization and the new politics of social solidarity. Cambridge: Cambridge University Press.

Thelen, K., \& Mahoney, J. (2010). Explaining institutional change: Ambiguity, agency, and power. Cambridge: Cambridge University Press.

UNESCO. (n.d.). Brazil, education and literacy. UNESCO. Retrieved from uis.unesco.org/country/BR

Velloso, J. (1987). Política educacional e recursos para o ensino: O salário-educação e a universidade. Caderno de Pesquisa, 61(1987), 3-28. 


\section{About the Authors}
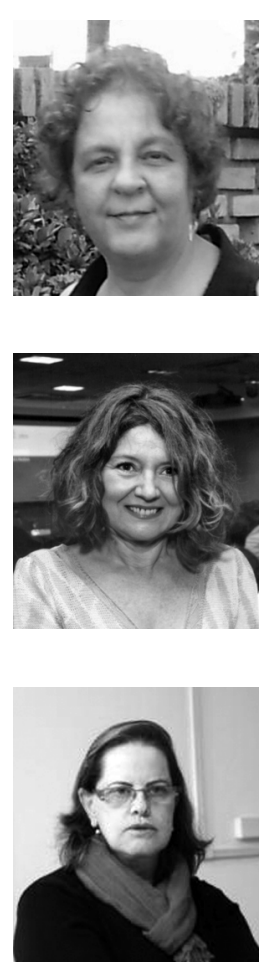

Elizabeth Balbachevsky is Associate Professor at the Department of Political Science at the University of São Paulo (USP), Brazil, Director of USP's Research Center on Public Policy Studies (NUPPs/ISP), and Fellow at the Laboratory of Studies in Higher Education, State University of Campinas. With Andrés Bernasconi (Catholic University of Chile), she is the Regional Editor for Latin America for the new International Encyclopedia of Higher Education, launched by Springer Editors in 2017. She is also member of the editorial board of the collection The Changing Academic Profession in A Comparative International Perspective (Springer Editors).

Helena Sampaio is Assistant Professor of the Department of Social Science and Education, Faculty of Education, State University of Campinas (Unicamp), Brazil. She is also Senior Researcher at the Laboratório de Estudos de Educação Superior (LEES)/Unicamp, Brazil. She holds a Master in Anthropology and a PhD in Political Science from the University of São Paulo, Brazil (USP). Currently her research focus are the processes of privatization and stratification in higher education, affirmative action, social inclusion policies and diversity in higher education.

Cibele Yahn de Andrade is a Researcher at the Center for Research in Public Policy at Unicamp since 1986. Cibele was the coordinator at Unicamp of the Regional Workshop for Education in Latin America and Caribe (OREAL/UNESCO) and of the regional Network for Educational Innovation (Red Innovemos). She is a Deputy Representative of the University of Campinas in the steering committee for Office of the Ombudsman at the Mayor's Office in Campinas. Her research interests are in the field of public policies for education, especially in studies related to the policies that affect the profile of supply and demand for higher education in Brazil. 